\title{
PENURUNAN KONSENTRASI KLOROFIL KRIM SUP Caulerpa racemosa YANG DIKERINGKAN DENGAN VACUUM DRYING OVEN
}

\author{
(Decreased Chlorophyll Concentration in Caulerpa racemosa Soup Cream \\ Dryed by Vacuum Drying Oven)
}

\author{
Dhanang Puspita $^{a^{*}}$, Windu Merdekawati ${ }^{b}$, Arisia Putri Sandy Mahendrac \\ aTeknologi Pangan, Universitas Kristen Satya Wacana, Salatiga, Indonesia \\ bMIPA-Biologi, Universitas Gadjah Mada, Yogyakarta, Indonesia \\ cllmu Gizi, Universitas Kristen Satya Wacana, Salatiga, Indenoesia \\ * Penulis korespondensi: \\ Email: dhanang.puspita@uksw.edu
}

\begin{abstract}
Caulerpa racemosa is a species of the green algae that can be used as raw material for cream soup. The added value to the cream soup is the presence of chlorophyll as bioactive compound and as natural pigment. The problem that occurs is that chlorophyll is not resistant to heat during processing. Vacuum drying oven is the solution to reduce chlorophyll denaturation due to heating. The purpose of this study was to determine the effect of temperature on chlorophyll content in the drying process of cream made from Caulerpa racemosa using a vacuum drying oven. The stages of this study; cream soup production, drying, chlorophyll extraction, and chlorophyll analysis. The results of this study obtained four temperature variations; $60,70,80$, and $90^{\circ} \mathrm{C}$. The highest chlorophyll content is at drying temperature of $60^{\circ} \mathrm{C}$, with the composition of chlorophyll a $(2,0786 \mu \mathrm{g} / \mathrm{mL})$, chlorophyll b $(1,8742 \mu \mathrm{g} / \mathrm{mL})$, and total chlorophyll $(3,9528$ $\mu \mathrm{g} / \mathrm{mL}$ ). Heat exposure causes chlorophyll to be unstable. Based on the result, it can be concluded that the optimal temperature for drying cream soup with a vacuum drying oven is $60^{\circ} \mathrm{C}$.
\end{abstract}

Keywords: Caulerpa racemosa, chlorophyll, pigment, vacuum drying oven

\begin{abstract}
ABSTRAK
Caulerpa racemosa adalah salah satu spesies alga hijau yang dapat dimanfaatkan sebagai bahan baku krim sup. Nilai tambah krim sup tersebut adalah adanya kandungan klorofil sebagai senyawa bioaktif dan sebagai pewarna alami. Permasalahn yang terjadi adalah klorofil tidak tahan terhadap panas pada saat pengolahan. Vacuum drying oven menjadi solusi untuk mengurangi kerusakan klorofil akibat pemanasan. Tujuan penelitian ini adalah mengetahui pengaruh suhu terhadap kandungan klorofil pada proses pengeringan krim sup yang terbuat dari Caulerpa racemosa dengan menggunakan vacuum drying oven. Tahapan penelitian ini meliputi, pembuatan krim sup, pengeringan, ekstraksi klorofil, dan analisis klorofil. Hasil penelitian ini diperoleh empat variasi suhu yakni $60,70,80$, dan $90^{\circ} \mathrm{C}$. Kandungan klorofil paling tinggi pada pengeringan dengan suhu $60^{\circ} \mathrm{C}$, dengan komposisi klorofil a $(2,0786 \mu \mathrm{g} / \mathrm{mL})$, klorofil b $(1,8742$ $\mu \mathrm{g} / \mathrm{mL})$, dan total klorofil $(3,9528 \mu \mathrm{g} / \mathrm{mL})$. Paparan panas menyebabkan klorofil menjadi tidak stabil. Berdasarkan data yang diperoleh dapat disimpulkan suhu optimal dalam mengeringkan krim sup dengan vacuum drying oven adalah $60^{\circ} \mathrm{C}$.
\end{abstract}

Kata kunci: Caulerpa racemosa, klorofil, pigmen, vacuum drying oven 


\section{PENDAHULUAN}

Krim sup adalah produk makanan kering yang dibuat dari tepung yang diberi bahan tambahan untuk meningkatkan nutrisi, rasa, aroma, warna, dan tekstur, yang penyajiannya di terlebih dahulu harus diseduh atau dipanaskan dengan air. Masyarakat pada umumnya mengonsumi krim sup sebagai sarapan (Setiawati, 2017). Selama ini, krim sup yang ada di pasaran tidak banyak yang memiliki variasi pada tampilannya. Tampilan krim sup identik dengan warna putih atau keabu-abuan. Kenampakan warna pada makanan menjadi salah satu faktor penentu dalam memilih sebuah produk pangan. Perlu adanya inovasi, untuk menciptakan tampilan warna yang menarik agar meningkatkan penerimaan masyarakat.

Klorofil adalah salah satu jenis pigmen pada tumbuhan yang menampilkan citra warna hijau. Klorofil sebagi pigmen alami sudah lama dijadikan pewarna alami pada makanan. Klorofil tidak hanya sebatas memberi warna, tetapi juga memiliki nilai tambah karena potensinya sebagai antioksidan, anti kanker, dan lain sebagainya. Klorofil memiliki sifat kelarutan yang baik dalam minyak ataupun air, sehingga bisa dijadikan pewarna pada krim sup.

Sumber klorofil banyak ditemukan di dalam semua jenis tumbuhan, beberapa jenis alga, dan bakteri. Salah satu sumber klorofil adalah pada rumput laut yakni Caulerpa racemosa. Jenis rumput laut ini terdistribusi di sepanjang perairan tropis. Caulerpa racemosa oleh masyarakat pesisir disebut sebagai anggur laut/latoh sebatas dimanfaatkan sebagai kudapan, lalapan, campuran pecel, dan makanan pendamping (Anwar, Bubun, \& Rosmawati, 2016), (Farid Ma 'ruf et al., 2013) (Dimara, Tuririday, Tien, \& Yenusi, 2012). Belum banyak yang memanfaatkan Caulerpa recemosa sebagai varian makanan yang lain, karena rasa dan aroma yang amis khas rumput laut.

Caulerpa racemosa adalah salah satu spesies rumput laut dari kelompok alga hijau
(Chlorophyta) yang tersebar di perairan tropis. Alga ini tumbuh melimpah dan seringkali menjadi ancaman ekologi karena laju pertumbuhannya dapat mengganggu pertumbuhan alga lain yang juga memiliki nilai ekonomis tinggi (Ornano et al., 2014). Pembuatan krim sup berbahan Caulerpa racemosa menjadi solusi guna meningkatkan nilai tambahnya.

Nilai gizi Caulerpa racemosa termasuk tinggi dibanding dengan jenis alga merah maupun cokelat. Caulerpa racemosa memiliki kandungan karbohidrat $48,68 \mathrm{mg} / \mathrm{g}$, lemak $8,68 \mathrm{mg} / \mathrm{g}$, dan protein $21,73 \mathrm{mg}$ (Farid Ma 'ruf et al., 2013). Meskipun nilai nutrisinya tinggi, namun kadar serat/selulosanya rendah dibandingkan yang lain. Rendahnya kadar serat pada Caulerpa racemosa membuat jenis alga ini tidak dapat menjadi bahan baku dalam produksi karagenan.

Caulerpa racemosa memiliki kandungan klorofil a $(10,08-17,4 \mu \mathrm{g} / \mathrm{mL})$ dan klorofil b $(15,2-31,2 \mu \mathrm{g} / \mathrm{mL})$ (Sarojini, Neelima, \& Sujata, 2015). Penelitian Sanchez et al. (2018) tentang klorofil pada Caulerpa racemosa melaporkan kandungan klorofil a $(3.0151 \pm 0.4273 \mu \mathrm{g} / \mathrm{mL}), \quad$ klorofil $\quad b$ (3.4289 $\pm 1.1454 \mu \mathrm{g} / \mathrm{mL}$ ) (Sanchez et al., 2018). Adanya kandungan klorofil menjadi alasan Caulerpa racemosa dimanfaatkan sebagai bahan pembuatan krim sup. Klorofil berperan sebagai pigmen alami sekaligus menjadi bahan tambahan pangan untuk pangan fungsional karena kandungan senyawa bioaktifnya.

Klorofil di dalam makanan dapat membatu dalam penyerapan zat gizi, membersihkan saluran pembuluh darah, menjaga $\mathrm{pH}$ darah (asam basa), mengurangi bau mulut, dan menjaga kesehatan sistem pencernaan. Manfaat lain dari klorofil adalah untuk meningkatkan imunitas tubuh, sumber energi, anti depresan pada susunan saraf pusat, mencegah konstipasi, perbaikan jaringan, dan membantu pembentukan hemoglobin (Merdekawati \& Susanto, 2009).

Krim sup berbasis rumput laut merupakan bentuk inovasi pangan dengan tujuan memanfaatkan potensi rumput laut 
dan nilai tambahnya, membuat produk pangan siap saji, memperpanjang umur simpan (6 - 12 bulan), menyederhanakan penyimpanan (tidak memerlukan lemari es), serta memiliki komposisi nutrien yang bisa diatur (sebagai pangan fungsional) (AbdelHaleem \& Omran, 2014).

Pemanfaatan Caulerpa recemosa sebagai salah satu bahan baku dalam pembuatan krim sup merupakan inovasi untuk menciptakan pangan baru berbasis rumput laut dan hasilnya berupa krim sup yang memiliki tampilan warna hijau sebagai nilai tambahnya. Kendala yang muncul adalah pada saat proses produksi krim sup dengan paparan panas untuk pengeringan. Suhu yang panas berpotensi mendegradasi kandungan klorofil. Klorofil sebagai pigmen yang bertanggung jawab terhadap pembentukan pigmen hijau tidak stabil terhadap paparan panas, asam, cahaya, $\mathrm{pH}$, dan oksigen (Wanda, Wibowo, \& Destiarti, 2017)

Pemanfaatan vacuum drying oven (VDO) adalah salah satu solusi untuk mengurangi kerusakan klorofil pada saat pengeringan krim sup. Prinsip kerja VDO yakni dengan mengeringkan dengan menggunakan tekanan hampa udara dan suhu yang rendah. Titik didih air dapat dimanipulasi dengan memberikan tekanan udara sehingga suhu didihnya bisa diturunkan. Dengan adanya rekayasa ini diharapkan bisa melindungi kandungan klorofil pada krim sup yang terbuat dari Caulerpa racemosa. Tujuan dari penelitian ini adalah mengetahui efek suhu pengeringan dengan vacuum drying oven untuk konservasi kandungan klorofil pada krim sup instan yang berbahan dasar Caulerpa racemosa.

\section{Bahan}

\section{BAHAN DAN METODE}

Penelitian ini dilakukan di Laboratorium Pengolahan Pangan UKSW. Tahapan penelitian meliputi proses produksi krim sup instan, ekstraksi klorofil, dan analisis klorofil. Bahan yang digunakan; Caulerpa racemosa, tepung terigu, tepung maizena, garam, bawang merah, bawang putih, aseton
(Merck), dan aquades. Alat yang digunakan; vacuum drying, blender, kain saring, mixer, loyang alumunium, penepung, ayakan 70 mesh, sentrifuge (Hetich), spektrofotometer UV-Vis (Genesys).

\section{Produksi Krim Sup}

Sebanyak 100gr Caulerpa racemosa dihaluskan menggunakan blender kemudian disaring menggunakan kain saring untuk didapatkan ekstrak pigmennya. Ekstrak pigmen kemudian ditambahkan aquades hingga dicapai volume $100 \mathrm{ml}$ kemudian ditambahkan tepung terigu 20gr, tepung maizena 10gr, bawang bombai 10gr, bawang putih $5 \mathrm{gr}$, dan garam $1 \mathrm{gr}$ lalu diaduk menggunakan mixer dengan kecepatan tinggi (Setiawati, 2017). Formulasi tersebut kemudian dipindahkan dalam loyang alumunium dan diratakan dengan ketebalan 2-4 mm lalu dimasukan dalam VDO dengan tekanan $-60 \pm 5 \mathrm{cmHg}$. Variabel suhu yang digunakan adalah $60,70,80$, dan $90^{\circ} \mathrm{C}$ selama 1,5-2 jam. Setelah kering kemudian dihaluskan dengan mesin penepung dan selanjutnya diayak dengan ayakan 70 mesh. Hasil krim sup kemudian disimpan dalam botol kaca tertutup untuk analisis lebih lanjut.

\section{Ekstraksi dan Analisis Klorofil}

Sebanyak $1 \mathrm{gr}$ ekstrak pigmen, produk krim sup (pengeringan suhu $60,70,80$, dan $90^{\circ} \mathrm{C}$ ) masing-masing dilarutkan dalam $10 \mathrm{ml}$ aseton $80 \%$. Masing-masing larutan kemudian disentrifugasi dengan kecepatan $4.000 \mathrm{rpm}$ selama 10 menit. Fraksi hasil sentrifugasi kemudian dipisahkan antara supernatan dan pellet. Supernatan kemudian dimasukan dalam botol kedap cahaya. Sebanyak $4 \mathrm{ml}$ supernatan dipindahkan dalam tabung kuvet lalu di analisis dengan menggunakan spektrofotometer pada $\star 662 \mathrm{~nm}$ dan $645 \mathrm{~nm}$ (Ritchie, 2008). Penghitungan klorofil dilakukan dengan dengan rumus:

Klorofil a $(\mu \mathrm{g} / \mathrm{mL})$ : $\left(11,75 \times \mathrm{A}_{662}\right)-\left(2,350 \times \mathrm{A}_{645}\right)$

Klorofil b $(\mu \mathrm{g} / \mathrm{mL})$ : $\left(18,61 \times A_{645}\right)-\left(3,960 \times{ }_{A 662}\right)$

Total Klorofil $(\mu \mathrm{g} / \mathrm{mL})$ : Klorofil a + Klorofil b 
Penghitungan dilakukan dengan 3 kali pengulangan (Sanchez, Villafranca, \& Lazaro, 2018) (Pratama \& Laily, 2015). Untuk mengetahui pola degradasi klorofil, dilakukan pemindaian menggunakan spektrofotometer UV-vis pada $\lambda 400$ 700nm (Johan, Jafri, Lim, \& Wan Maznah, 2014).

\section{HASIL DAN PEMBAHASAN}

Hasil pengolahan Caulerpa racemosa menjadi krim sup ditunjukan pada Gambar 1. Pada gambar tersebut ada 2 bentuk produk yakni di bagian bawah adalah serbuk dari krim sup, sedangkan yang bagian atas adalah hasil ekstraksi klorofilnya, sebagai pembanding digunakan ekstrak klorofil Caulerpa recemosa segar. Pengeringan pada suhu $60^{\circ} \mathrm{C}$ memiliki warna yang lebih kuat dibandingkan dengan suhu pengeringan yang lain. Pada pengeringan dengan suhu $70-90^{\circ} \mathrm{C}$ terjadi perubahan warna yakni dengan warna hijau yang semakin pudar. Hasil ekstraksi klorofil pada Caulerpa recemosa segar menunjukan warna hijau tua/pekat.

Pada Caulerpa racemosa diketahui terdapat 4 jenis pigmen yakni; yaitu xantofil, klorofil b, klorofil a, dan feofitin. Xantofil merupakan senyawa pigmen turunan karotenoid yang terkandung dalam pigmen klorofil. Klorofil merupagan pigmen warna hijau dan terdapat 5 jenis fraksinya, dengan sifat polaritas yang berbeda-beda. Feoftin merupakan pigmen cokelat kehitaman yang merupakan senyawa turunan klorofil. Feofitin terbentuk karena adanya perubahan enzimatis, paparan panas dan asam, serta proses fermentasi (Dimara et al., 2012).

\section{Degradasi Klorofil}

Klorofil merupakan pigmen warna hijau yang tersimpan dalam kloroplas. Organisme yang memiliki kloroplas, sebagian besar di dalamnya terdapat 2 jenis klorofil yakni klorofil $a$ dan klorofil $b$. Klorofil $a$ berwarna biru hijau, sedangkan klorofil $b$ berwarna hijau kekuningan. Klorofil sangat rentan terdegradasi terhadap berbagai faktor eksternal diantaranya panas.

Proses produksi krim sup melibatkan panas untuk tahap pengeringannya. Paparan panas menyebabkan degradasi klorofil sehingga terjadi reaksi feofitinasi yang akan menghasilkan feofitin. Feofitin adalah salah satu produk degradasi klorofil karena hilangnya ion $\mathrm{Mg}^{2+}$. Reaksi feofitinasi dimulai saat paparan panas mendenaturasi protein yang berikatan dengan klorofil. Protein yang seharusnya melindungi klorofil akan terlepas karena paparan panas, sehingga klorofil menjadi tidak stabil. $\mathrm{Mg}^{2+}$ yang seharusnya berada di dalam molekul protein akan terlepas dan digantikan oleh hidrogen. Secara visual dapat dilihat dengan adanya perubahan warna menjadi hijau kecoklatan.

Paparan panas juga menyebabkan ketidakstabilan klorofil karena adanya reaksi pembentukan klorofilid. Reaksi klorofilid terjadi akibat adanya aktivitas enzim klorofilase. Pada kondisi normal, enzim klorofilase mengikat kuat pada lipoprotein lamela. Adanya ikatan ini maka tidak terjadi hidrolisis klorofil. Enzim klorofilase akan aktif pada suhu $65-75^{\circ} \mathrm{C}$ saat dilarutkan dalam air. Pada penelitian ini, larutan krim sup mendapat paparan suhu $60-90^{\circ} \mathrm{C}$, sehingga terjadi degradasi protein yang disebabkan oleh reaksi pembentukan feofitin dan klorofilid.

Lipova et al (2010), mengatakan jika pemanasan hingga suhu $50^{\circ} \mathrm{C}$ belum menyebabkan degradasi yang signifikan terhadap klorofil. Pada pemanasan 60 $90^{\circ} \mathrm{C}$ mulai terjadi degradasi yang signifikan. Pada suhu 60 - $70^{\circ} \mathrm{C}$ terjadi degradasi klorofil karena lepasnya molekul klorofil. Pelepasan molekul ini bertahan hingga pada suhu $80^{\circ} \mathrm{C}$, sedangkan pada suhu $90^{\circ} \mathrm{C}$ akan menyebabkan kehancuran. Paparan panas sebaikya pada suhu tidak lebih dari $60^{\circ} \mathrm{C}$, karena jika melebihi suhu tersebut kan merusak membran tilakoid dan mengarah pada pembentukan radikal bebas (Lípová, Krchňák, Komenda, \& llík, 2010). 


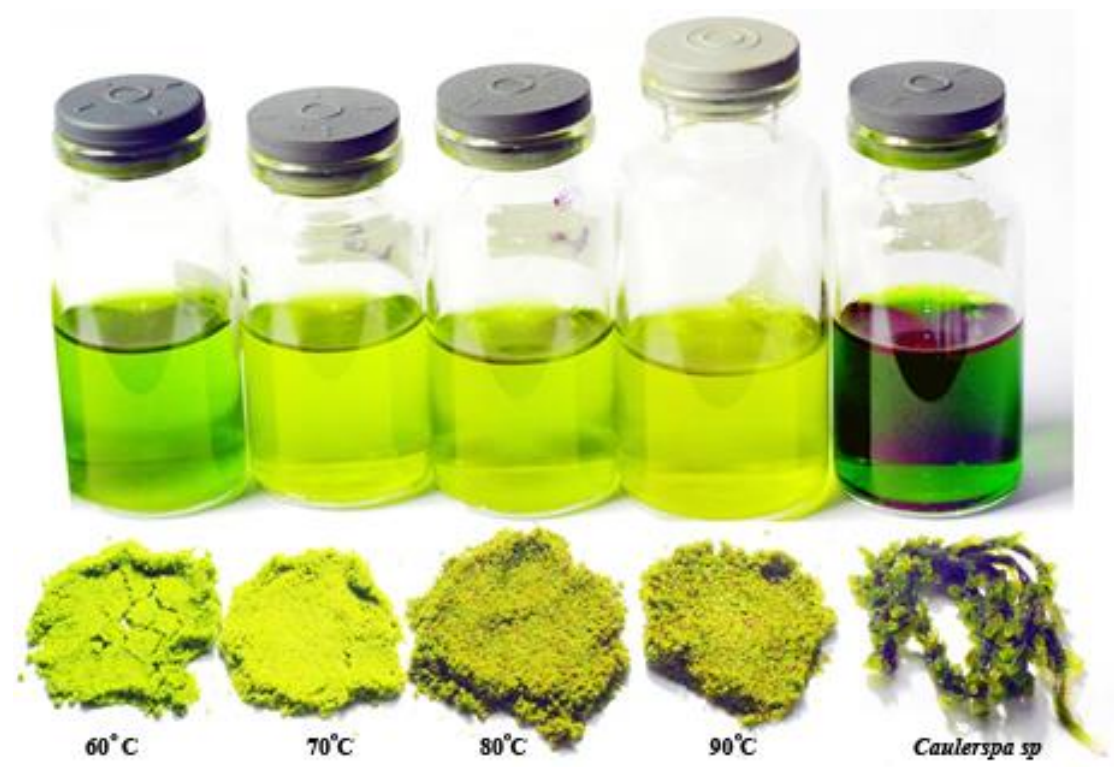

Gambar 1. Warna produk krim sup Caulerpa sp dan ekstrak klorofilnya.

Tabel 1. Kandungan Klorofil krim sup dari Caulerpa racemosa $(\mu \mathrm{g} / \mathrm{mL})$

\begin{tabular}{|c|c|c|c|c|c|}
\hline \multirow{2}{*}{ Parameter } & \multicolumn{4}{|c|}{ Suhu Pengeringan $\left({ }^{\circ} \mathrm{C}\right)$} & \multirow{2}{*}{ Caulerpa sp } \\
\hline & 60 & 70 & 80 & 90 & \\
\hline & 1,442 & 0,553 & 0,533 & 0,444 & 2,578 \\
\hline \multirow[t]{3}{*}{$A_{645}$} & 1,446 & 0,553 & 0,532 & 0,446 & 2,585 \\
\hline & 1,447 & 0,551 & 0,531 & 0,445 & 2,574 \\
\hline & 2,055 & 0,822 & 0,968 & 0,787 & 3,080 \\
\hline \multirow[t]{3}{*}{$A_{662}$} & 2,060 & 0,823 & 0,965 & 0,788 & 3,113 \\
\hline & 2,059 & 0,823 & 0,963 & 0,788 & 3,053 \\
\hline & 2,0758 & 0,8358 & 1,0121 & 0,8204 & 3,0132 \\
\hline \multirow[t]{2}{*}{ Klorofil a } & 2,0807 & 0,8371 & 1,0089 & 0,8210 & 3,0503 \\
\hline & 2,0793 & 0,8375 & 1,0067 & 0,8213 & 2,9824 \\
\hline Rerata Klorofil a & 2,0786 & 0,8368 & 1,0092 & 0,8209 & 3,0153 \\
\hline Standar Deviasi & 0,0025 & 0,0008 & 0,0027 & 0,0005 & 0,0340 \\
\hline & 1,8698 & 0,7036 & 0,6086 & 0,5146 & 3,5779 \\
\hline \multirow[t]{2}{*}{ Klorofil b } & 1,8752 & 0,7032 & 0,6079 & 0,5179 & 3,5779 \\
\hline & 1,8770 & 0,6995 & 0,6068 & 0,5161 & 3,5812 \\
\hline Rerata Klorofil b & 1,8742 & 0,7021 & 0,6078 & 0,5162 & 3,5790 \\
\hline Standar Deviasi & 0,0039 & 0,0023 & 0,0009 & 0,0017 & 0,0019 \\
\hline Total Klorofil & 3,9528 & 1,5389 & 1,6170 & 1,3372 & 6,5943 \\
\hline
\end{tabular}

Pada pemaparan panas pada suhu $60^{\circ} \mathrm{C}$, kandungan klorofil tersisa sebesar 39,53 $\mu \mathrm{g} / \mathrm{mL}$, artinya sudah terjadi degradasi sekitar $26,42 \mu \mathrm{g} / \mathrm{mL}$. Pada pemaansan $70^{\circ} \mathrm{C}$ dan $80^{\circ} \mathrm{C}$ terjadi degradasi klorofil sebesar $50,56 \mu \mathrm{g} / \mathrm{mL}$ dan $49,77 \mu \mathrm{g} / \mathrm{mL}$. Pada rentang tersebut kemungkinan degradasi klorofil disebabkan oleh enzim klorofilase, karena pada suhu $75^{\circ} \mathrm{C}$ enzim tersebut bekerja secara maksimal. Pada pengeringan dengan suhu $90^{\circ} \mathrm{C}$, kandungan klorofil tersisa sebesar $13,37 \mu \mathrm{g} / \mathrm{mL}$ atau mengalami 
kerusakan sebesar $52,57 \mu \mathrm{g} / \mathrm{mL}$. Kerusakan pada pemanasan ini kemungkinan disebabkan oleh pembentukan peofitin yang ditandai dengan kenampakan warna hijau kecoklatan, demikian juga pada suhu $80^{\circ} \mathrm{C}$.

Kandungan klorofil secara kuantitatif ditunjukan pada tabel 1. Pada tabel tersebut disajikan kandungan klorofil dari proses pengeringan krim sup pada suhu $60-90^{\circ} \mathrm{C}$. Terjadi penurunan kandungan klorofil dari ekstrak segar Caulerpa racemosa dan yang sudah diproses dengan pengeringan $60^{\circ} \mathrm{C}$ yakni tinggal $59,96 \%$. Dengan proses pemanasan pada suhu $70^{\circ} \mathrm{C}$ tersisa klorofil sebesar $23,33 \%, 80^{\circ} \mathrm{C}(24,53 \%)$, dan $90^{\circ} \mathrm{C}$ $(20,28 \%)$.

Hasil perhitungan kandungan klorofil ditunjukkan pada Tabel 1. Selanjutnya dilakukan perhitungan persentase penurunan kandungan klorofil masingmasing krim sup dengan variasi suhu pengeringan terhadap klorofil pada ekstrak segar Caulerpa recemosa. Berdasarkan data yang diperoleh menunjukkan kadar kandungan klorofil yang tersisa pada tiap variasi suhu yaitu sebesar $59,96 \%\left(60^{\circ} \mathrm{C}\right)$, $23,33 \%$ ( $\left.70^{\circ} \mathrm{C}\right), 24,53 \%\left(80^{\circ} \mathrm{C}\right)$ dan $20,28 \%$ $(90 \stackrel{\circ}{\circ})$.

Pola degradasi klorofil dapat dilihat pada Gambar 2. Pada gambar tersebut terlihat 2 puncak serapan di sekitar panjang gelombang 645 dan $662 \mathrm{~nm}$ dengan perubahan absorbansi yang jelas antara Caulerpa racemosa segar dengan produk yang sudah dikeringkan pada suhu 60,70 , 80 , dan $90^{\circ} \mathrm{C}$. Absorbansi pada puncak serapan berbanding terbalik dengan kenaikan suhu, semakin tinggi suhu pengeringan, puncak serapan semakin menurun absorbansinya.

\section{Suhu Pengeringan Optimal}

Optimalisasi adalah cara yang bertujuan untuk mendapatkan hasil yang maksimal dengan upaya yang efektif dan efisien. Pemaparan panas dilakukan dengan melepas pasokan energi kalor untuk menguapkan air. Proses penguapan air berkontribusi pada kerusakan material (senyawa bioaktif) yang tidak stabil terhadap panas. Semakin tinggi suhu diberikan, maka energi yang diberikan akan semakin banyak. Begitu juga dengan kualitas produk yang rentan terhadap panas akan rusak pada paparan panas yang semakin meningkat.

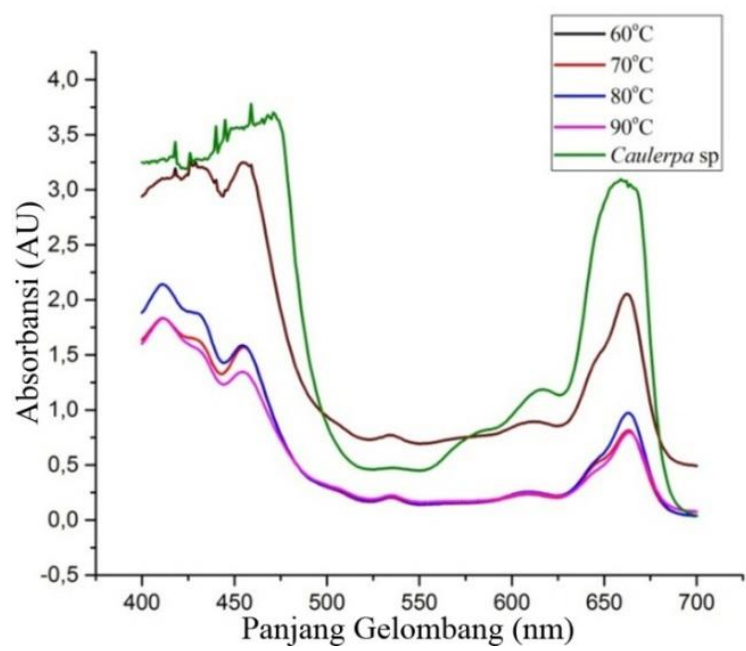

Gambar 2. Pola degradasi klorofil krim sup akibat paparan panas.

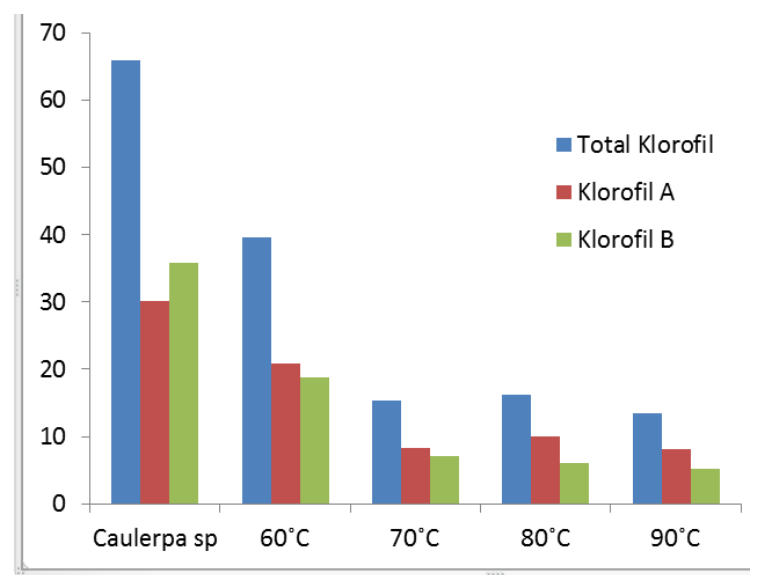

Gambar 3. Kandungan klorofil pada krim sup instan dengan pengeringan dengan berbagai variasi suhu.

Untuk mendapatkan optimalisasi pengeringan maka harus dicari besaran panas dan tingkat kerusakan material. Besaran panas merupakan banyaknya energi kalor yang harus dipenetrasikan. Semakin besar energi yang dikeluarkan, maka seiring dengan biaya yang harus dikeluarkan. Tingkat kerusakan berkaitan dengan seberapa banyak bahan aktif yang 
hilang atau terdegradasi selama pemanasan. Semakin tinggi kerusakan, maka kualitas produk akan semakin menurun. Proses yang ideal adalah dengan mengeluarkan energi sekecil mungkin dan meminimalisir kerusakan senyawa bioaktif.

Dalam skala produksi industri, akan dicari titik pengeringan yang optimal dengan mempertimbangkan seminimal mungkin energi yang dikeluarkan, serta kerusakan yang paling sedikit. Pada Gambar 3 dapat dijelaskan secara deskriptif, pada pengeringan dengan suhu $60^{\circ} \mathrm{C}$ kandungan total klorofil, klorofil $a$ dan $b$ adalah yang tertinggi dibandingkan suhu 70, 80, dan $90^{\circ} \mathrm{C}$. Energi yang dibutuhkan untuk mengeluarkan panas pada seting suhu $60^{\circ} \mathrm{C}$ juga lebih sedikit dibandingkan dengan suhu di atasnya. Pada penelitian ini belum diteliti tentang aspek waktu pengeringan, karena hanya dengan estimasi $1-1,5$ jam pemanasan dengan target krim sup dapat ditepungkan.

\section{KESIMPULAN}

Dari penelitian ini dapat disimpulkan, Caulerpa racemosa dapat dimanfaatkan sebagai bahan baku krim sup dengan klorofil sebagai nilai tambahnya. Semakin tinggi suhu pengeringan menyebabkan degradasi kandungan klorofil pada krim sup. Pengeringan yang optimal adalah suhu $60^{\circ} \mathrm{C}$ ditandai dengan warna hijau yang masih kuat dan tingkat degradasi klorofil yang paling sedikit dibandingkan dengan suhu > $60^{\circ} \mathrm{C}$.

\section{UCAPAN TERIMA KASIH}

Penulis mengucapkan terimakasih kepada Bonifacius Arbanto, yang telah menyediakan sampel rumput laut. Diucapkan juga terimakasih kepada laboratorium Carotenoid and Antioxidant Research Center untuk analisis pigmennya.

\section{DAFTAR PUSTAKA}

Abdel-Haleem, A. M. H., \& Omran, A. A. 2014. Preparation of Dried Vegetarian

Soup Supplemented with Some Legumes. Food and Nutrition Sciences,
05(22), 2274-2285. https://doi.org/10.4236/fns.2014.522241

Anwar, L. O., Bubun, R. L., \& Rosmawati. 2016. Manfaat Anggur Laut (Caulerpa Racemosa) dan Penanganannya dengan Melibatkan Masyarakat Pantai di Desa Rumba-rumab. In Senaspro 2016 (pp. 110-116).

Dimara, L., Tuririday, H., Tien, D., \& Yenusi, N. B. 2012. Identifikasi dan Fotodegradasi Pigmen Klorofil Rumput Laut Caulerpa racemosa (Forsskal) J.Agardh. Jurnal Biologi Papua, 4(2), 4753.

Farid Ma 'ruf, W., Ibrahim, R., Dewi, E. N., Susanto, E., Amalia, U., Teknologi, L., ... Semarang, T. 2013. Profil Rumput Laut Caulerpa racemosa dan Gracilaria verrucosa Sebagai Edible Food. Jurnal Saintek Perikanan, 9(1), 68-74.

Johan, F., Jafri, M. Z., Lim, H. S., \& Wan Maznah, W. O. 2014. Laboratory measurement: Chlorophyll-a concentration measurement with acetone method using spectrophotometer. In IEEE International Conference on Industrial Engineering and Engineering Management (pp. 744748).

https://doi.org/10.1109/IEEM.2014.7058 737

Lípová, L., Krchňák, P., Komenda, J., \& Ilík, P. 2010. Heat-induced disassembly and degradation of chlorophyll-containing protein complexes in vivo. Biochimica et Biophysica Acta - Bioenergetics, 1797(1), 63-70. https://doi.org/10.1016/j.bbabio.2009.08. 001

Merdekawati, W., \& Susanto, A. B. 2009. Kandungan dan komposisi pigmen rumput laut serta potensinya untuk kesehatan. Squalen, 4(2), 41-47. 
https://doi.org/10.15578/squalen.v4i2.14 7

Ornano, L., Donno, Y., Sanna, C., Ballero, M., Serafini, M., \& Bianco, A. 2014. Phytochemical study of Caulerpa racemosa (Forsk.) J. Agarth, an invading alga in the habitat of la Maddalena archipelago. Natural Product Research, 28(20), 1795-1799. https://doi.org/10.1080/14786419.2014. 945928

Pratama, A. J., \& Laily, A. N. 2015. Analisis Kandungan Klorofil Gandasuli (Hedychium gardnerianum Shephard ex Ker-Gawl) pada Tiga Daerah Perkembangan Daun yang Berbeda. In Seminar Nasional Konservasi dan Pemanfaatan Sumber Daya Alam (pp. 216-219). https://doi.org/10.1016/B978044452072-2/50025-2

Ritchie, R. J. 2008. Universal chlorophyll equations for estimating chlorophylls a, $\mathrm{b}, \mathrm{c}$, and $\mathrm{d}$ and total chlorophylls in natural assemblages of photosynthetic organisms using acetone, methanol, or ethanol solvents. Photosynthetica, 46(1),
115-126.

https://doi.org/10.1007/s11099-008-

0019-7

Sanchez, I. A. V, Villafranca, M. C. R., \& Lazaro, N. 2018. Estimation of chlorophyll content in local Caulerpa seaweeds using acetone, DMSO and Methanol, 8(10), 1-5.

Sarojini, Y., Neelima, P., \& Sujata, B. 2015. The seasonal variations in distribution of photosynthetic pigments in four edible species of Chlorophyceae and the effect of light, dissolved oxygen and nutrients on their distribution. Annals of Biological Research, 6(3), 36-40. Retrieved from http://scholarsresearchlibrary.com/archiv e.html

Setiawati, T. 2017. Sweet potato cream soup sebagai alternatif bisnis makanan sehat, 9(1),1-6.

Wanda, P., Wibowo, M. A., \& Destiarti, L. 2017. Enkapsulasi dan Uji Stabilitas Ekstrak Metanol Daun Pepaya (Carica papaya. Linn). JKK, 6(1), 25-29. https://doi.org/10.1016/S00404039(00)61549-6 